\title{
Pengembangan Laboratorium Matematika Virtual Dengan Software Appy Pie Untuk Meningkatkan Kemampuan Komunikasi Dan Adaptive E-Learning
}

\section{Developing Virtual Mathematical Laboratorium Using Appy Pie Software for Encourage Communication Skill and Adaptive E-learning}

\author{
Isna Kholifa ${ }^{1^{*}}$, Suswanti ${ }^{2}$, Nuryadi ${ }^{3}$ \\ ${ }^{1,2,3}$ Jurusan Pendidikan Matematika, Universitas Mercu Buana Yogyakarta. \\ Jalan Wates Km. 10 Sedayu Yogyakarta, 55753 \\ *Korespondensi Penulis. E-mail: isnakholifa@mercubuana-yogya.ac.id Telp: +6281228106535
}

\begin{abstract}
Abstrak
Tujuan penelitian ini adalah untuk menghasilkan media pembelajaran matematika virtual berbasis Android ditinjau dari kemampuan komunikasi dan adaptive e-learning yang valid, praktis, dan efektif. Media pembelajaran matematika virtual yang dihasilkan berbasis Android pada materi pokok bilangan dibuat dengan bantuan software Appy Pie yang berisikan teks, gambar, video, link, dan game interaktif. Prosedur pengembangan media matematika virtual menggunakan 5 tahapan yaitu analisis, perancangan, pengembangan, implementasi, dan evaluasi. Uji coba yang dilakukan meliputi ujicoba ahli/validasi ahli (expert judgement), uji coba kelompok kecil (small group try-out) dan uji coba lapangan (field try-out). Uji coba lapangan (field try-out) dilakukan pada dua kelas X di SMA N 1 Sedayu. Instrumen penelitian yang digunakan adalah lembar validasi, lembar penilaian kepraktisan oleh guru, lembar penilaian kepraktisan oleh siswa, dan instrumen tes keefektifan media. Analisis data dilakukan dengan mengkonversi total skor data kuantitatif yang diperoleh menjadi data kualitatif skala lima. Hasil penelitian ini menunjukkan bahwa media matematika virtual berbasis Android dengan berbantukan software Appy Pie memenuhi kriteria valid, praktis dan efektif ditinjau dari kemampuan komunikasi dan adaptive e learning.
\end{abstract}

Kata Kunci: pengembangan, adaptive e learning, appy pie, komunikasi matematis

\begin{abstract}
The research aims to produce virtual mathematics learning media Android based through communication ability and adaptive e-learning which valid, practice, and effective, virtual mathematics learning media which produced based Android in the material cardinal number produce with Appy Pie software which consist of text, picture, video, link, and interactive game. The procedure of development virtual mathematics through 5 steps they are analysis, design, development, implementation, and evaluation. Try-out which conducted include expert try-out/ expert judgment, small group try-out and field try-out. Field try-out conducted in two classes of Eleven Grade students in SMA Negeri 1 Sedayu. Research instrument which used are validation sheet, teacher's practice assessment sheet, students' practice assessment sheet, and media instrument effectiveness test. Data analysis held by converse the total score quantitative data obtained into five scale of qualitative data. The result of the research shows that virtual mathematics learning media Android based by using Appy Pie software fulfill the criteria of valid, practice, and effective through communication ability and adaptive e-learning.
\end{abstract}

Keyword: developing, adaptive e-learning, appy pie, mathematics communication

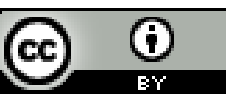

DOI: https://dx.doi.org/10.26486/jm.v3i2.876

W : http://ejurnal.mercubuana-yogya.ac.id/index.php/mercumatika

E : mercumatika@mercubuana-yogya.ac.id 


\section{PENDAHULUAN}

Perkembangan Teknologi Informasi Komunikasi (TIK) menuntut terciptanya inovasi dalam semua bidang, salah satunya adalah pendidikan. Semakin banyak siswa yang memiliki komputer/laptop di rumah bahkan memegang piranti hand-phone yang digunakan untuk mengunduh dan mengunggah melalui jaringan internet. Komputer dulunya dipergunakan hanya sebatas pengolah data (word processing) dan alat bantu bantu menghitung, namun seiring dengan kemajuan teknologi maka komputer telah bergeser dengan kemampuannya dalam mengakses atau menjalankan program-program pembelajaran yang dikemas dalam bentuk multimedia[1]. Bahkan handphone juga sudah dapat digunakan untuk membuat multimedia maupun alat peraga interaktif.

Lebih lanjut, mengutip hasil penelitian eksperimen yang dilakukan oleh Edward, dkk yang berhasil mengungkapkan bahwa pembelajaran dengan menggunakan multimedia interaktif memberikan hasil yang lebih baik secara signifikan $(\alpha=0,05)$ dibanding dengan pembelajaran yang menggunakan buku teks[1]. Multimedia interaktif merupakan kombinasi beberapa jenis media menjadi satu ke dalam satu aplikasi komputer dengan disertai aspek yang menarik minat siswa, seperti gambar, animasi, warna, grafik digital, dan suara[2].

Namun demikian hanya 20-25\% yang memenuhi syarat dan layak digunakan untuk kerperluan pendidikan[1]. Hasil survey yang dilakukan Opera pada tahun 2013 di Indonesia menunjukkan bahwa 10\% pengguna Handphone Android adalah umur 13 - 17 tahun[3]. Hal ini membuktikan bahwa anak dengan usia tingkat SMP sampai SMA memliki perhatian yang cukup besar dalam penggunaan smartphone. Fakta seperti ini merupakan suatu tantangan yang perlu disikapi dengan segera untuk mengembangakan laboratorium pembelajaran matematika virtual yang berisi komponen materi, game matematika, dan soal-soal latihan.

Laboratorium matematika virtual ini dalam bentuk aplikasi yang dapat diunggah dalam google playstore pada Android (m-learning). Android adalah sistem operasi Linux yang diperuntukkan untuk mobile device, karena memliki kelebihan seperti sifat open source yang memberikan kebebasan para pengembang untuk menciptakan aplikasi[4]. Pembuatan laboratorium matematika virtual dalam android dengan menggunakan platform yang sudah tersedia di internet yaitu http://appypie.com. Appy Pie adalah salah satu online builder yang tersedia di internet untuk pembuatan aplikasi berbasis Android, Windows Phone, dan HTML 5. Appy Pie menyediakan template dalam pembuatan aplikasi android harus terkoneksi internet secara online. Materi pelajaran yang diisi dapat berupa teks, gambar, video, link, dan game interaktif[3].

Mengimplementasikan kemampuan komunikasi matematika dan adaptive e-learning dalam membangun laboratorium pembelajaran matematika virtual diharapkan dapat menghasilkan sarana pembelajaran yang efektif. Komunikasi matematis bisa dilihat dari kemampuan siswa dalam menggunakan bahasa matematis untuk mengungkapkan ide atau gagasannya terkait dengan permasalahan yang ia hadapi. Menurut Elliot \& Kenney menyatakan bahwa jika kita sepakat bahwa matematika adalah bahasa dan bahasa dipelajari dengan baik dalam komunitas pelajar maka akan mempermudah pemahaman[5].

Bagi dunia keilmuan, matematika merupakan bahasa simbolik yang memungkinkan terjadinya komuikasi yang cermat dan tepat. Oleh karena itu, komunikasi matematis memegang peranan yang penting sebagai representasi dari pemahaman siswa terhadap konsep matematika itu sendiri atau bagi ilmu-ilmu yang lain. Kemampuan komunikasi matematis harus digali dan dikembangkan guru dalam pembelajaran matematika agar siswa memiliki kemampuan untuk memberikan informasi yang padat, singkat dan akurat tentang nilai-nilai yang dibahasakan. Dengan demikian kemampuan komunikasi matematis yang merupakan salah satu tujuan penyelenggaraan pembelajaran matematika terpenuh.

Menurut Sugiman, Adaptive e-learning merupakan bentuk pengajaran dan pembelajaran yang menggunakan rangkaian elektronik untuk menyampaiakan isi, interaksi ataupun segi penggunaan media berbasis website atau software [6]. Pemanfaatan e-learning dalam pembelajaran matematika membawa pengaruh tejadinya proses transformasi pendidikan konvensional ke dalam bentuk digital, baik secara isi maupun sistemnya. Inovasi terbaru open source application dari University of New South Wales (UNSW) ini dapat dimanfaatkan di Indonesia untuk membangun laboratorium virtual yang sangat diperlukan ketika laboratorium secara fisik sangat sulit dijangkau. 
Yang diperlukan hanyalah akses ke internet untuk memperoleh aplikasi adaptive elearning tersebut.

Pembuatan laboratorium pembelajaran matematika virtual ini nantinya dengan bantuan software Appy Pie secara online di sekolah dengan biaya terjangkau, namun efektif dan efisien dalam menunjang pembelajaran. Penelitian ini untuk mewujudkan aplikasi laboratorium pembelajaran matematika virtual yang dapat didownload di Android yang berisikan buku materi pelajaran, video pembelajaran, game matematika, dan latihan soal-soal yang terupdate.

Masalah yang diangkat dalam penelitian ini adalah: (1) Bagaimanakah mengembangkan laboratorium pembelajaran matematika virtual dengan software Appy Pie yang baik atau valid dalam meningkatkan kemampuan komunikasi dan Adaptive e-learning?; (2) Seberapa tingkat keefektifan laboratorium pembelajaran matematika virtual dengan software Appy Pie yang baik dalam meningkatkan kemampuan komunikasi dan Adaptive e-learning?.

\section{METODE}

Penelitian ini merupakan jenis penelitian pengembangan, yaitu suatu proses penelitian yang digunakan untuk mengembangkan suatu produk. Produk yang dihasilkan dari penelitian ini berupa produk aplikasi laboratorium pembelajaran matematika dalam bentuk mobile learning yang dapat diakses dalam android. Dalam penelitian pengembangan ini peneliti mengikuti prosedur pengembangan media ADDIE (Analysis, Design, Development, Implementation, Evaluation).

Objek penelitian dalam penelitian ini adalah pengembangan laboratorium pembelajaran matematika virtual. Untuk keperluan pengembangan laboratorium pembelajaran matematika virtual, diperlukan bantuan dari beberapa pihak yaitu:

\section{Guru Matematika dan siswa SMA N 1 Sedayu Kab. Bantul DIY}

Seorang guru matematika SMA N 1 Sedayu Kab. Bantul memberikan tanggapan dan masukan tentang penggunaan laboratorium virtual dalam pembelajaran matematika. Sedangkan siswa kelas $\mathrm{X}$ dilibatkan dalam tahap implementasi yang meliputi uji coba media dalam kegiatan pembelajaran.

\section{Ahli media dan ahli materi}

Untuk validasi produk multimedia yang dikembangkan dari aspek pembelajaran dan materi, dipilih dua orang ahli materi dari dosen program studi matematika Universitas Negeri Yogyakarta. Untuk validasi produk multimedia yang dikembangkan dari aspek media, dipilih dua ahli media dari PPPTK Matematika Daerah Istimewa Yogyakarta.

Prosedur dalam mengembangkan software media pembelajaran matematika virtual ini, peneliti mengacu pada model pengembangan ADDIE yang meliputi 5 tahap, yaitu: analysis (analisis), design (perancangan), development (produksi), implementation (implementasi), evaluation (evaluaasi).

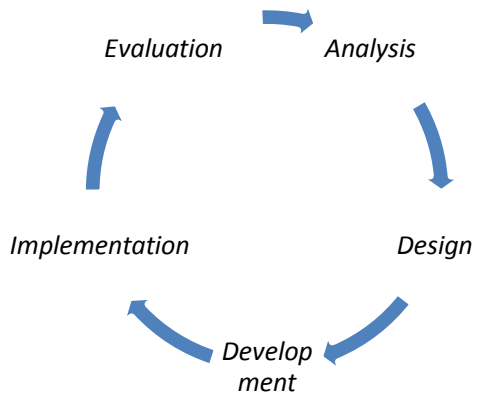

Gambar 1. Model Pengembangan Laboratorium Pembelajaran Matematika

1. Analisis: pada tahap ini kegiatan yang dilakukan adalah menganalisis kebutuhan dan karasteristik siswa, menganalisis kurikulum untuk menetapkan kompetensi hasil belajar, memilih dan menetapkan materi pokok yang akan dikembangkan, dan mengembangkan alat evaluasi.

2. Desain: pada tahap ini, pengembangan membuat storyboard dan flowchart

3. Produksi: pada tahap ini dilakukan pengemasan materi ke dalam CD sesuai storyboard yang telah dibuat 
a. Implementasi : dalam tahap ini, akan dilakukan uji coba. sebelum uji coba dilaksanakan, dilakukan review oleh ahli materi dan ahli media terhadap produk multimedia yang dikembangkan.

b. Kemudian dilakukan uji coba dengan langkah-langkah sebagai berikut : (a) Uji coba satu lawan satu;(b)Uji coba kelompok kecil;(c)Uji coba kelompok besar/uji coba lapangan. Revisi dilakukan setiap selesai melakukan uji coba yang berdasarkan saran dan kritik dari subyek coba.

4. Evaluation: dalam tahap ini akan dilakukan evaluasi media pembelajaran yang telah dibuat berdasarkan hasil angket evaluasi media pembelajaran. Berdasarkan hasil evaluasi ini selanjutnya dapat diketahui karakteristik laboratorium pembelajaran matematika virtual yang diharapkan.

Kualitas produk, pendesainan, pengembangan, dan pengevaluasian program harus memenuhi kriteria valid, praktis, dan efektif[7].

1. Kevalidan Perangkat Pembelajaran

Kualitas produk dikatakan valid dilihat dari keterkaitannya dengan tujuan dari pengembangan produk itu sendiri harus benar-benar dipertimbangkan[7]. Selanjutnya, untuk menggambarkan kriteria kevalidan produk pembelajaran yaitu apabila perangkat pembelajaran dapat menggambarkan kurikulum yang diharapkan atau intended, yakni kombinasi antara ideal dan formal.

\section{Kepraktisan Perangkat Pembelajaran}

Kepraktisan dilihat dari pendapat oleh pengguna terutama guru dan siswa yang menganggap produk yang dihasilkan mudah untuk digunakan dan juga menggambarkan proses pembelajaran yang aktual[7]. Ini dimaksudkan adanya kekonsistenan antara intended dan perceived curriculum dan intended and operational curriculum.

\section{Keefektifan Produk}

Indeks keefektifan adalah persentase yang menjelaskan: (a) level penguasaan yang dicapai oleh siswa untuk tiap tujuan pembelajaran; (b) rata-rata pencapaian tujuan oleh semua siswa. Persentase penguasaan ditentukan oleh guru setelah melaksanakan pembelajaran. Lebih lanjut dikatakan bahwa batas penguasaan standar keberhasilan adalah $75 \%$, sebagaimana yang ditentukan BSNP bahwa kriteria ideal ketuntasan untuk masing-masing indikator adalah 75\%[9].

Data yang diperoleh dari angket validasi ahli dianalisis berdasarkan langkah-langkah berikut:

1. Penilaian oleh ahli dirangkum dalam satu tabel yang disebut tabel hasil penilaian kelayakan produk.

2. Pemeriksaan terhadap setiap hasil penilaian oleh ahli.

3. Mengolah data pada masing-masing aspek yang dinilai yang meliputi: (a) Aspek kognitif Intrinsik; (b) Aspek kognitif ekstra; (c) Aspek kualitas materi matematika; (d) Aspek Syarat Didakdik; (e) Aspek Syarat Konstruksi; dan (f) Aspek Syarat Teknis.

4. Membuat kriteria hasil penilaian sebagaimana disajikan pada tabel kriteria berikut. Produk yang dinilai dikatakan baik atau valid apabila kriteria yang didapatkan adalah Baik atau Sangat Baik. Adapun tabel 1 di bawah ini merupakan kriteria yang digunakan adalah sebagai berikut:

\begin{tabular}{ccl}
\multicolumn{3}{c}{ Tabel 1. Skala Pedoman Penilaian[10] } \\
\hline Interval Skor & Nilai & \multicolumn{1}{c}{ Kriteria } \\
\hline$X_{i}+2 S B_{i} \leq X$ & A & Sangat Baik \\
$X_{i}+S B_{i} \leq X<X_{i}+2 S B_{i}$ & B & Baik \\
$X_{i}-S B_{i} \leq X<X_{i}+S B_{i}$ & C & Cukup Baik \\
$X_{i}-2 S B_{i} \leq X<X_{i}-S B_{i}$ & D & Kurang Baik \\
$X<X_{i}-2 S B_{i}$ & E & Tidak Baik \\
\hline
\end{tabular}

Hasil penilaian, baik dari ahli materi maupun ahli media dan juga siswa, jika sudah memberikan penilaian akhir (keseluruhan) dengan nilai minimal "B", maka produk laboratorium pembelajaran matematika virtual hasil pengembangan tersebut sudah dianggap layak untuk digunakan.

Data kepraktisan multimedia pembelajaran matematika diperoleh dari penilaian guru dan siswa terhadap multimedia pembelajaran matematika. Kepraktisan multimedia pembelajaran matematika yang dikembangkan diukur berdasarkan hasil penilaian dari guru dan siswa yang 
menggunakan produk pada saat uji coba. Skor penilaian yang diperoleh dari guru dan siswa dikonversi menjadi data kualitatif skala lima dengan mengacu pada konversi pada tabel 2.

Banyak item untuk penilaian siswa adalah 10 item dan penilaian dilakukan oleh 64 orang siswa (skor maksimum ideal $=245$, skor minimum ideal $=49, \overline{x_{l}}=147$ dan SBi $=33$ ). Banyak item untuk penilaian guru adalah 10 item dan penilaian dilakukan oleh satu orang guru (skor maksimum ideal $=50$, skor minimum ideal $=10, \bar{x}_{l}=3$ dan SBi $=0,33$ ), sehingga diperoleh kriteria interval kepraktisan menurut penilaian siswa dan guru seperti pada tabel 2 berikut:

Tabel 2. Kriteria Interval Kepraktisan

\begin{tabular}{ccc}
\multicolumn{2}{c}{ Interval } & \multirow{2}{*}{ Nilai } \\
\cline { 1 - 2 } Penilaian Siswa & Penilaian Guru & \\
\cline { 1 - 2 }$X>206$ & $X>4$ & $\mathrm{~A}$ \\
$173<X \leq 206$ & $3,33<X \leq 4$ & $\mathrm{~B}$ \\
$121<X \leq 173$ & $2,67<X \leq 3,33$ & $\mathrm{C}$ \\
$88<X \leq 121$ & $2<X \leq 2,67$ & $\mathrm{D}$ \\
$X \leq 88$ & $X \leq 2$ & $\mathrm{E}$ \\
\hline
\end{tabular}

Multimedia pembelajaran matematika yang dikembangkan dikatakan praktis jika penilaian kepraktisan perangkat pembelajaran oleh guru dan siswa konsisten minimal berada pada kategori baik.

Analisis terhadap keefektifan media pembelajaran matematika virtual berbasis Android dilakukan terhadap adaptive e learning dan kemampuan komunikasi yang diperoleh oleh siswa. Untuk menilai keefektifan yang ditinjau dari kemampuan pemecahan masalah siswa digunakan tabel skala lima.

Langkah-langkah dalam analisis data adalah sebagai berikut:

1) Menghitung skor tiap siswa

2) Menghitung frekuensi siswa yang mencapai tingkat hasil belajar yang ditentukan, atau Kriteria Ketuntasan Minimal (KKM) yang telah ditetapkan, yaitu 75.

3) Menentukan ketercapaian hasil belajar untuk seluruh siswa dan menyimpulkan berdasarkan kriteria yang telah ditetapkan yaitu jika $80 \%$ siswa mencapai skor 75 maka multimedia pembelajaran matematika dapat dikatakan efektif.

4) Hasil pekerjaan siswa diperiksa dan dinilai berdasarkan pedoman penskoran. Nilai maksimal untuk hasil belajar adalah 100. Hasil belajar dikatakan efektif/tuntas secara individual jika mencapai Kriteria Ketuntasan Minimal (KKM) yang ditetapkan sekolah yaitu 75, sedangkan keefektifan klasikal tercapai jika paling sedikit $80 \%$ siswa subjek uji coba mencapai kriteria ketuntasan individual.

\section{HASIL DAN PEMBAHASAN \\ Prototype Media Pembelajaran}

Pengembangan media pembelajaran matematika virtual berbasis Android dikembangkan dengan beberapa tahapan. Adapun tahapan-tahapan tersebut adalah sebagai berikut:

\section{Tahap I}

1) Menganalisis Kompetensi Dasar menggunakan bilangan real dalam pemecahan masalah yang berkaitan dengan bilangan rasional, bilangan irasional, dan sifat operasi dalam bilangan real untuk disampaikan melalui media pembelajaran virtual berbasis Android. Proses ini meliputi kajian materi matematika yang sesuai dengan kompetensi dasar.

2) Mengumpulkan referensi mengenai materi pokok bilangan real. Pemilihan kompetensi dasar menggunakan bilangan real dalam pemecahan masalah yang berkaitan dengan mengidentifikasi bilangan rasional, bilangan irasional, dan sifat operasi dalam bilangan real karena pada standar kompetensi tersebut hasil belajar siswa masih banyak yang masih dibawah KKM (hasil pra survei yang dilakukan di SMA N 1 Sedayu Bantul). Selain itu, nilai ujian nasional (UN) di SMA N 1 Sedayu pada standar kompetensi tersebut selama tiga tahun terakhir mengalami penurunan (laporan BSNP).

3) Merencanakan dan memilih jenis media pembelajaran yang akan digunakan. Media pembelajaran yang dipilih yaitu berupa aplikasi pembelajaran yang dapat digunakan dengan perangkat Android. Pemilihan ini dikarenakan pengemasan dalam bentuk aplikasi sangat efektif karena mempunyai memori yang cukup besar dan tidak mudah terhapus, selain itu multimedia 
pembelajaran ini dibuat menggunakan program Adobe Flash CS 5 yang penggunaannya harus menggunakan komputer.

\section{Tahap II}

Pembuatan multimedia pembelajaran ini membahas tentang standar kompetensi menggunakan bilangan real dalam pemecahan masalah yang berkaitan dengan bilangan rasional, bilangan irasional, dan sifat operasi dalam bilangan real dalam penarikan kesimpulan dan pemecahan masalah. Tahap ini merupakan desain awal pembuatan multimedia pembelajaran matematika yang dikembangkan. Desain tersebut menggambarkan alur halaman yang tersedia pada multimedia mulai dari halaman pembuka hingga halaman penutup. Pembuatan multimedia pembelajaran matematika mengacu pada desain ini.

\section{Validitas Media Pembelajaran}

Melakukan validasi media pembelajaran virtual berbasis Android yang telah direvisi kepada ahli materi dan pembelajaran, ahli media, dan siswa (kelas besar dan kelas kecil) disertai instrumen penilaian kesesuaian media pembelajaran.

Pertama deskripsi data kevalidan berdasarkan penilaian ahli materi dan pembelajaran terhadap laoboratorium matematika virtual. Ahli Materi dan Pembelajaran yang terdiri dari 3 orang memberikan penilaian terhadap kevalidan multimedia pembelajaran matematika. Hasil penilaian kevalidan ini digunakan sebagai prasyarat dilaksanakannya uji kelas kecil. Data penilaian ahli materi dan pembelajaran disajikan dalam tabel 3 berikut:

Tabel 3. Penilaian Ahli Materi dan Pembelajaran Matematika

\begin{tabular}{cccccc}
\hline \multirow{2}{*}{$\mathbf{P}$} & \multicolumn{5}{c}{ Persentase Penilaian siswa (N=64) } \\
\cline { 2 - 6 } & SK & $\mathbf{K}$ & $\mathbf{C}$ & $\mathbf{B}$ & SB \\
\hline P1 & 0 & 0 & 41,67 & 41,67 & 16,67 \\
P2 & 0 & 0 & 0 & 33,33 & 66,67 \\
P3 & 0 & 0 & 41,67 & 41,67 & 16,67 \\
P4 & 0 & 8,33 & 25 & 41,67 & 25 \\
P5 & 0 & 0 & 0 & 41,67 & 58,33 \\
P6 & 0 & 8,33 & 8,33 & 75 & 8,33 \\
P7 & 0 & 25 & 25 & 25 & 25 \\
P8 & 0 & 8,33 & 16,67 & 33,33 & 41,67 \\
P9 & 0 & 0 & & 41,67 & 58,33 \\
P10 & 0 & 16,67 & 25 & 41,67 & 16,67 \\
Total & 0 & 66,67 & 183,33 & 416,67 & 333,33 \\
\hline
\end{tabular}

Kedua, deskripsi data kevalidan berdasarkan penilaian ahli media terhadap multimedia pembelajaran matematika

Data penilaian ahli media terhadap multimedia pembelajaran matematika untuk siswa SMA disajikan dalam tabel 4 berikut.

\section{Ujicoba Media Skala Kecil}

\begin{tabular}{ccc}
\multicolumn{3}{c}{ Tabel 4. Penilaian Ahli Media } \\
\cline { 3 - 4 } P & \multicolumn{2}{c}{ Skor } \\
\cline { 2 - 3 } & Ahli 1 & Ahli 2 \\
P1 & 4 & 4 \\
P2 & 5 & 4 \\
P3 & 4 & 4 \\
P4 & 5 & 4 \\
P5 & 5 & 5 \\
P6 & 5 & 5 \\
P7 & 4 & 4 \\
P8 & 4 & 5 \\
P9 & 4 & 5 \\
Total & 40 & 40 \\
\hline
\end{tabular}

Data Penilaian siswa pada saat ujicoba terbatas terhadap multimedia pembelajaran matematika SMA pada kompetensi Dasar materi bilangan real disajikan dalam tabel 5 berikut: 
Tabel 5. Data Kepraktisan Media Pembelajaran Berdasarkan Persentase Penilaian Siswa

\begin{tabular}{cccccc}
\hline P & \multicolumn{5}{c}{ Persentase Penilaian siswa (N=64) } \\
\cline { 2 - 6 } P1 & SK & K & C & B & SB \\
P2 & 0 & 0 & 41,67 & 41,67 & 16,67 \\
P3 & 0 & 0 & 0 & 33,33 & 66,67 \\
P4 & 0 & 8,33 & 25 & 41,67 & 25 \\
P5 & 0 & 0 & 0 & 41,67 & 58,33 \\
P6 & 0 & 8,33 & 8,33 & 75 & 8,33 \\
P7 & 0 & 25 & 25 & 25 & 25 \\
P8 & 0 & 8,33 & 16,67 & 33,33 & 41,67 \\
P9 & 0 & 0 & & 41,67 & 58,33 \\
P10 & 0 & 16,67 & 25 & 41,67 & 16,67 \\
Total & 0 & 66,67 & 183,33 & 416,67 & 333,33 \\
\hline
\end{tabular}

\section{Data Hasil Uji Coba Kelas Besar}

Pertama, deskripsi data kepraktisan berdasarkan penilaian siswa (kelompok besar) dan guru terhadap laboratorium matematika virtual. Adapun data penilaian siswa pada saat uji coba lapangan terhadap Laboratorium Matematika virtual pembelajaran matematika SMA disajikan dalam tabel 6 berikut.

Tabel 6. Penilaian Guru pada Saat Ujicoba Kelas Besar

\begin{tabular}{ccc}
\hline P & Skor & Rata-rata \\
\cline { 2 - 3 } P1 & Guru & 4 \\
P2 & 4 & 4 \\
P3 & 4 & 4 \\
P4 & 3 & 3 \\
P5 & 4 & 4 \\
P6 & 4 & 4 \\
P7 & 5 & 5 \\
P8 & 5 & 4 \\
P9 & 4 & 4 \\
P10 & 4 & 4 \\
Total & 41 & 40 \\
\hline
\end{tabular}

\section{Analisis Data}

Analisis Kevalidan Laboratorium Pembelajaran Matematika Virtual

Untuk menganalisis kevalidan produk digunakan dua data, yaitu penilaian ahli materi dan pembelajaran matematika, dan penilaian ahli media terhadap media pembelajaran matematika virtual. 
Tabel 7. Data Skor Kevalidan

\begin{tabular}{lcl}
\hline \multicolumn{1}{c}{ Aspek } & Skor & Kategori \\
\hline $\begin{array}{l}\text { Materi dan } \\
\text { Pembelajaran }\end{array}$ & 60,33 & $\begin{array}{l}\text { Sangat } \\
\text { Matematika }\end{array}$ \\
$\begin{array}{l}\text { Laboratorium } \\
\text { Matematika Virtual }\end{array}$ & 40 & $\begin{array}{l}\text { Sangat } \\
\text { Baik }\end{array}$ \\
\hline
\end{tabular}

Dari Tabel 7 di atas skor diperoleh untuk kevalidan produk dari aspek materi dan pembelajaran matematika yaitu 60,33 , dimana berada pada rentang skor di atas 56 sehingga kevalidan produk dari aspek materi dan pembelajaran matematika termasuk kategori sangat baik. sedangkan skor kevalidan yang diperoleh dari aspek media yaitu 40 yang berada pada rentang 36 , sehingga kevalidan produk dari aspek media termasuk dalam kategori sangat baik.

Penilaian kevalidan produk dari ahli materi dan pembelajaran dan ahli media secara konsisten menyatakan sangat baik. Oleh karena itu, dari data yang diperoleh dari penilaian oleh ahli materi dan pembelajaran matematika, dan ahli media dapat disimpulkan bahwa produk yang dikembangkan yaitu berupa multimedia pembelajaran matematika dapat dinyatakan sangat valid sehingga layak digunakan.

\section{Analisis Kepraktisan Laboratorium Pembelajaran Matematika}

Untuk mengetahui kepraktisan produk yang dikembangkan data yang digunakan adalah data tentang penilaian guru dan siswa terhadap multimedia pembelajaran matematika. Berdasarkan lembar angket yang diberikan kepada 64 siswa dan 1 guru matematika, diperoleh data tentang penilaian siswa dan guru terhadap multimedia pembelajaran matematika seperti telah disajikan pada tabel 8 berikut ini:

Tabel 8. Data Skor Kepraktisan Media Pembelajaran Matematika

\begin{tabular}{lcl}
\hline Penilai & Skor & \multicolumn{1}{c}{ Kategori } \\
\hline Siswa & 201,6 & Sangat Baik \\
Guru & 4,0 & Baik \\
\hline
\end{tabular}

Dari Tabel 8 di atas skor yang diperoleh untuk kepraktisan produk berdasarkan penilaian siswa yaitu 201,6 yang berada pada rentang skor di atas 196 sehingga kepraktisan produk berdasarkan penilaian siswa termasuk kategori sangat baik. sedangkan skor kepraktisan yang diperoleh dari penilaian guru yaitu 4,0 yang berada pada rentang 3,33-4, sehingga kepraktisan produk berdasarkan penilaian guru termasuk dalam kategori baik. Penilaian kepraktisan produk dari siswa dan guru secara konsisten menyatakan baik. Oleh karena itu, dari data yang diperoleh dari penilaian siswa dan guru dapat disimpulkan bahwa produk yang dikembangkan yaitu berupa multimedia Spembelajaran matematika dapat dinyatakan praktis sehingga layak digunakan.

\section{Analisis Keefektifan Laboratorium Pembelajaran Matematika Virtual}

Untuk mengetahui keefektifan Laboratorium pembelajaran matematika virtual yang dikembangkan ditinjau dari kemampuan komunikasi dan Adaptive e-learning. Berdasarkan data tes matematika siswa kelas VIII, sebanyak 64 siswa diperoleh hasil analisis seperti pada table 9 berikut:

Tabel 9. Analisis Data Tes

\begin{tabular}{lccc}
\hline Jenis Tes & $\begin{array}{c}\text { Jumlah } \\
\text { siswa }\end{array}$ & $\begin{array}{c}\text { Jumlah } \\
\text { siswa } \\
\text { tuntas }\end{array}$ & Persentase \\
\hline $\begin{array}{l}\text { Kemampuan } \\
\text { Komunikasi } \\
\text { Adaptive e- } \\
\text { learning }\end{array}$ & 64 & 53 & $82,81 \%$ \\
\hline
\end{tabular}

Berdasarkan tabel 9 diatas Persentase ketuntasan siswa untuk yaitu 82,81\% ditinjau dari kemampuan komunikasi dan untuk adaptive e-learning mencapai 93,75\%. Hal ini menunjukkan bahwa ketuntasan individu siswa telah mencapai batas minimum ketuntasan yaitu $75 \%$. Sehingga dapat disimpulkan bahwa produk yang dikembangkan efektif ditinjau dari kemampuan komunikasi dan adaptive e-learning. 


\section{Kajian Produk Akhir}

Setelah dilakukan serangkaian tahap pengembangan, diperoleh produk akhir yang berupa laboratorium pembelajaran matematika virtual. Produk tersebut telah dinyatakan valid, praktis, dan efektif melalui analisis yang dilakukan terhadap data-data yang diperoleh. Produk yang dikembangkan ini telah melalui proses validasi dan penilaian dengan melakukan revisi sebanyak 3 kali. Laboratorium pembelajaran matematika ini juga ditujukan untuk meningkatkan kemampuan komunikasi matematis dan pemecahan masalah dalam belajar matematika. Kualitas produk yang dikembangakn sjuga dinyatakan sangat baik berdasarkan penilai ahli materi dan pembelajaran matematika, ahli media dan siswa sehingga layak digunakan untuk skala yang lebih besar. Produk ini dirancang sebagai media pembelajaran yang dapat digunakan guru untuk menyampaikan materi dikelas. Produk laboratorium pembelajaran matematika juga dapat diakses di http://labpmat.mercubuana-yogya.ac.id dan dapat di download lewat google playstore dengan klik "virtualmaths".

\section{SIMPULAN}

Berdasarkan hasil penelitian dan pembahasan diperoleh simpulan sebagai berikut: Pertama, produk yang dikembangkan berupa Laboratorium pembelajaran matematika virtual dengan bantuan software Appy Pie. Produk ini telah diujicobakan di SMA Negeri 1 Sedayu kabupaten Bantul dan dapat diakses atau diunggah melalui laman http://labpmat.mercubuana-yogya.ac.id dengan nama produk "virtualmaths" s,ehingga layak digunakan dalam kegiatan pembelajaran dengan skala yang lebih luas. Kedua, hasil pengembangan yang berupa Laboratorium pembelajaran matematika virtual dinyatakan sangat valid berdasarkan penilaian ahli materi dan pembelajaran, dan ahli media. Penilaian ahli-ahli tersebut secara konsisten mengkategorikan Laboratorium pembelajaran matematika virtual dalam kategori sangat valid. Ketiga, hasil pengembangan yang berupa Laboratorium pembelajaran matematika virtual dinyatakan praktis berdasarkan penilaian guru dan siswa. Penilaian guru dan siswa secara konsisten mengkategorikan multimedia pembelajaran matematika dalam kategori praktis. Keempat, hasil pengembangan yang berupa Laboratorium pembelajaran matematika virtual dinyatakan efektif berdasarkan hasil tes kemampuan komunikasi dan adaptive e-learning siswa. Dari hasil tes tersebut siswa secara konsisten menyatakan bahwa Laboratorium pembelajaran matematika virtual efektif ditinjau dari kemampuan komunikasi dan adaptive e-learning.

\section{DAFTAR PUSTAKA}

Anggraeni, R.D., \& Kustijono, R. 2013. Pegembangan Media Animasi Fisika Pada Materi Cahaya dengan Aplikasi Flash Berbasis Android. Jurnal Pendidikan Fisika dan Aplikasinya (JPFA) Vol.3 No.1, Juni 2013. ISSN: 2087-9946.

Azwar, S. 2010. Tes Prestasi. Yogyakarta: Pustaka Belajar.

BSNP. 2006. Panduan penyusunan kurikulum tingkat satuan pendidikan jenjang pendidikan dasar dan menengah. Jakarta: Badan Standar Nasional Pendidikan.

Geisert, P. G., \& Mynga. 1995. Teachers, Computer and Curriculum: Microcomputer in the classroom. United State of America: Allyn \& Bacon.

Irnin, A., dkk. 2016. Pembuatan Media Pembelajaran Berbasis Android. Jakarta: Universitas Indrapati PGRI.

Kemp, E.J. 1994. Instructional design: a play for unit and course development ( $2^{\text {nd }}$ ed). New York: Meriil.

Munir. 2008. Kurikulum Berbasis Teknologi dan Komunikasi. Bandung: Alfabeta.

Nuryadi, N., \& Khuzaini, N. (2016). The Effectiveness of Team's Game Tournament Seen From Communication and Problem Solveing Capabilities (Experimental Study of Class VIII students in SMP Negeri 1 Seyegan). Jurnal Mercumatika: Jurnal Penelitian Matematika dan Pendidikan Matematika, 1(1). 
Nuryadi, N. (2019). Pengembangan Media Matematika Mobile Learning Berbasis Android ditinjau dari Kemampuan Pemecahan Masalah. Jurnal pendidikan surya edukasi (JPSE), 5(1), 1-13.

Nieveen. 1999. Prototyping to Reach Product Quality dalam Plomp, T; Nieveen, N., Gustafson, K, Branch, R.M, \& Van den Akker, $J(e d s)$. Design approaches and tools in education and training. London: Kluwer Acadenic Publlisher. 